\title{
Hoax and Hate Speech: Social Media andthe Rise of Tribal Nationalism in 2019 Indonesia Presidential Election
}

\author{
Budihardjo $^{1}$, Winarno ${ }^{2}, \mathrm{M} \mathrm{Zuhri}^{3}$, N Malihah ${ }^{4}, \mathrm{H} \mathrm{Syaifuddin}^{5}, \mathrm{G}_{\text {Cahyono }}{ }^{6}$ \\ Institut Agama Islam Indonesia (IAIN), Salatiga ${ }^{1,2,3,4,6}$ \\ Universitas Islam Negeri (UIN) Maulana Malik Ibrahim Malang, Jawa Timur, Indonesia ${ }^{5}$ \\ \{budi_stain@yahoo.co.id\}
}

\begin{abstract}
This article discusses the relationship between social media and the Indonesian presidential election in 2019. It is not surprising that sectarianism and racism have played some significant roles in the election and social media. Both of them were used frequently during the campaign and have contributed to the polarization among Indonesians. However, to set the contestation among ordinary citizens on social media in an opposed binary is incorrect. Marked by the utilization of volunteers, buzzers, and micro-celebrities, the Indonesia presidential election in 2019 has exemplified post-truth politics by utilizing volunteers, buzzers, and some celebrities. While encouraging freedom of expression, social media is used not only to encourage freedom of expression but also to encourage freedom of hate speech; to voice their opinions but silence others. Thus, it is clear that social media and electoral politics have a complex relation. Therefore, it is suggested that there should be mutual shaping between users and algorithms results forming "algorithmic enclaves" which may produce some forms of tribal nationalism. Within these multiple online enclaves, social media users claim and legitimize their own versions of nationalism by excluding equality and justice for others.
\end{abstract}

Keywords: Social Media, IndonesiaElectoral Politics, Nationalism

\section{Introduction}

The stages of the Indonesia presidential election have finished. The next stage is the inauguration of the President and Vice President scheduled to be held on October 20, 2019. However, the 2019 presidential election process has left various problems especially with the use of social media. Social media has been used for political information, for example, to share and disseminate information, to discuss issues around politics with social media users and voters ( Michaelsen, 2011), (Arshad, Ali \& Hassan, 2014), [3]. Social media did not cause divisiveness among voters in this election. However, as politics has become increasingly entangled with social media, online and offline political talk and action are no longer separate [4].

Social media's potential for politics has enthused optimistic pronouncements on digital empowerment and the renewal of public spheres. This optimistic and, at times, utopian view 
underline how social media platforms increase civic exchanges among citizens [5], encourage citizen engagement [6], transform political participation (Cogburn and Espinoza-Vasquez 2011), and facilitate citizen journalism that promotes transparency [7]. Critics have been equally swift to dispute this utopian view by pointing the dark sides of social media usage such as state and market surveillance [8], the loss of privacy [9], the decline of quality information [10], the proliferation of untruths (recently called "fake news") [11], and the rise of online radical groups.

\section{Method}

This study uses a qualitative approach with a descriptive method to describe a systematically constructed discourse in hoax news with Norman Fairclough Discourse Analysis as a scalpel. The unit of analysis in this research is content analysis. Content analysis is a method used in analyzing text. In this research, researchers prefer content analysis with the definition of Klaus Krippendorf [12], where content analysis is a research technique for making replicable and valid inferences from data to their context. For this reason, Krippendorf emphasizes two important things, namely (i) elements that can be replicated in which research must be carried out by another researcher in different environment, using the same technique as data and producing the same research; (ii) context elements in which research with content analysis methods must pay attention to the context of the data element which will be analyzed as political hoax news on a number of websites or news portals.

Data were collected from all news in social media (Facebook and WhatsApp) containing hoax and hate speech which were posted from January to June 2019. The procedures of data collection are taken in several steps. First, any news containing hoax and hate speech posted Facebook and WhatsApp were identified and taken noted. Second, the data collected in the first step were categorized based on themes. Third, the data collected in the second step were identified more detailed to specifically select any hoax and hate speech relating to Presidential Candidate Joko Widodo and Presidential Candidate Prabowo Subianto.

The collected data were analyzed using Fairlclough Discourse Analysis Model to obtain valid research results. Finally, the data were analyzed on the basis of Political Communication study to get a picture of the news containing hoax in Indonesia

\section{Result and Discussion}

In 2019, the Indonesian people celebrated the XXX IndonesiaPresidential Election. General elections in Indonesia have certainly been going a long time ago. Looking at the history of 1955 was the first general election held in Indonesia. Elections at that time aim to elect the DPRalong with the Constituents that existed in the era of Soekarno's leadership [13]. Whereas in the presidential and vice-presidential elections, the system is carried out in two ways. First, direct elections (popular model election) are candidates who get voted most are determined as elected presidents, while in indirect elections (electoral-college) is carried out through the vote portion of the people's representatives (Provincial DPRD or Regency DPRD /City) which became the people's representation in the presidential election with a vote of more than 50\%. Candidates who get the most votes are determined as winners in the election directly. Whereas in indirect elections, candidates who get $50 \%$ of their representatives will be elected president [14].

During this time the presidential election held after the legislative elections resulted in a fragile coalition of political parties (not strong). Experience shows that government produced 
in 4 (four) times Post-reform elections often experience divided government. This is indicated by a number of circumstances, including The mechanism of mutual oversight and balance between the Dewan Perwakilan Rakyat(DPR) or House of Representatives and the President is not working well; The pairs of candidates for President and Vice President often create tactical relationship partnerships that are momentary with political parties, so that they do not create a joint collaboration between long-term political parties which can create a simplification of the number of political parties naturally. In practice, a model for nominating pairs of candidates for President and Vice President by the combination of political parties does not always form a combination of permanent cooperation from political parties in the parliament, and it is unable to realize the simplification of our party system. In fact, our party system is increasingly fragmented [15]. Presidential elections in Indonesia are held every five years.

\section{Hoax and Hate Speech}

A hoax is a piece of information that did not actually happen. Hoax is usually called fake news. Hoax is usually used as a joke or humor, for example like April Fool. However, hoaxes are also used by some parties who want to do making a good image or as a venue to benefit themselves.

The characteristics of hoax according to the Press Council are as follows:

a. Hoaxes can cause anxiety, hatred, and hostility.

b. The source of the hoax is unclear. Hoax in social media usually comes from media reports that are not verified, unbalanced and tend to denounce certain parties.

c. Hoax includes fanaticism in the name of ideology, provocative titles, and introduction provides punishments and conceals facts and data.

Other characteristics of hoaxes usually use capital letters and bold, there is an exclamation mark and there is no clear source of information

There have been several works to investigate news containing hoax and hate speech in Indonesia (Salam, 2018; Lim, 2017; Sirajuddin et al, 2017; Astuti, 2019; Kusuma and Lubis, 2016). This current research reveals a phenomenon of news containing hoax and hates speech during the 2019 presidential election.

During the 2019 presidential election, hoax news was used by a handful of elements as a medium to provoke the public in the interests of certain parties. The emergence of various hoax news that has circulated widely in the community has greatly affected the survival of the state. This is, because hoax gave a great impact on the integrity of the Indonesian nation. Hoax news has spread widely in various media, both through printed and online media. Unfortunately, many people seemed to swallow the raw - the hoax news as true without finding out the truth and sources from which the news originated. Most Indonesian people easily believe in hoax news and without being reluctant to spread the news whose truth is still questioned.

Hate Speech is communication actions carried out by an individual or groups in the form of provocation, provocation, or insults to other individuals or groups in terms of various aspects such asrace, color, gender, disability, sexual orientation, nationality, religion, and others. spreading hate speech news, Hate Speech is forms of intolerance 


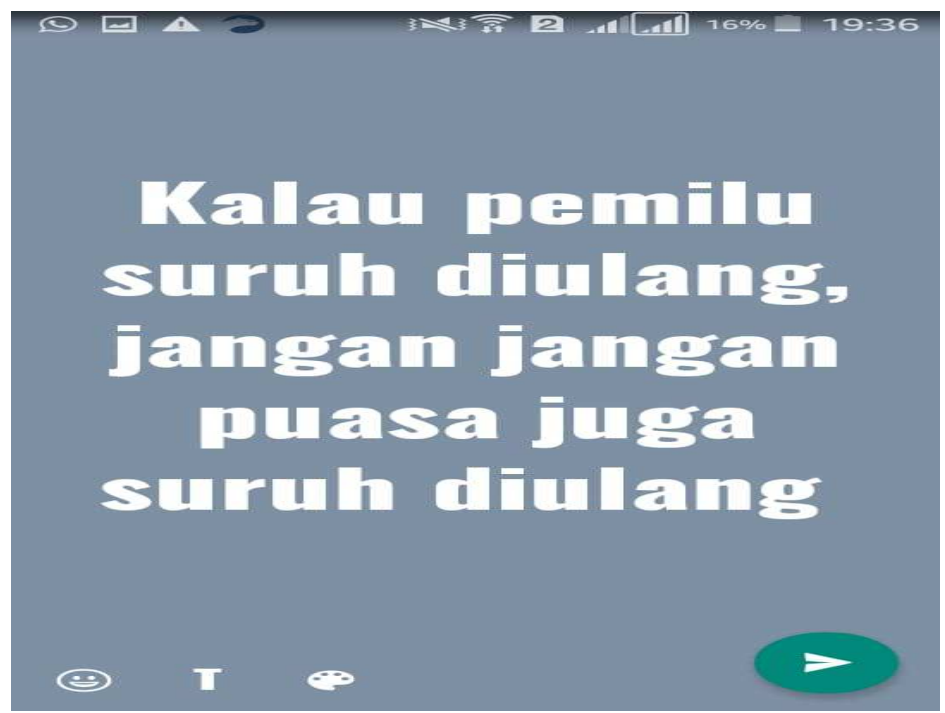

Fig. 1. Hoax and Hate Speech 1

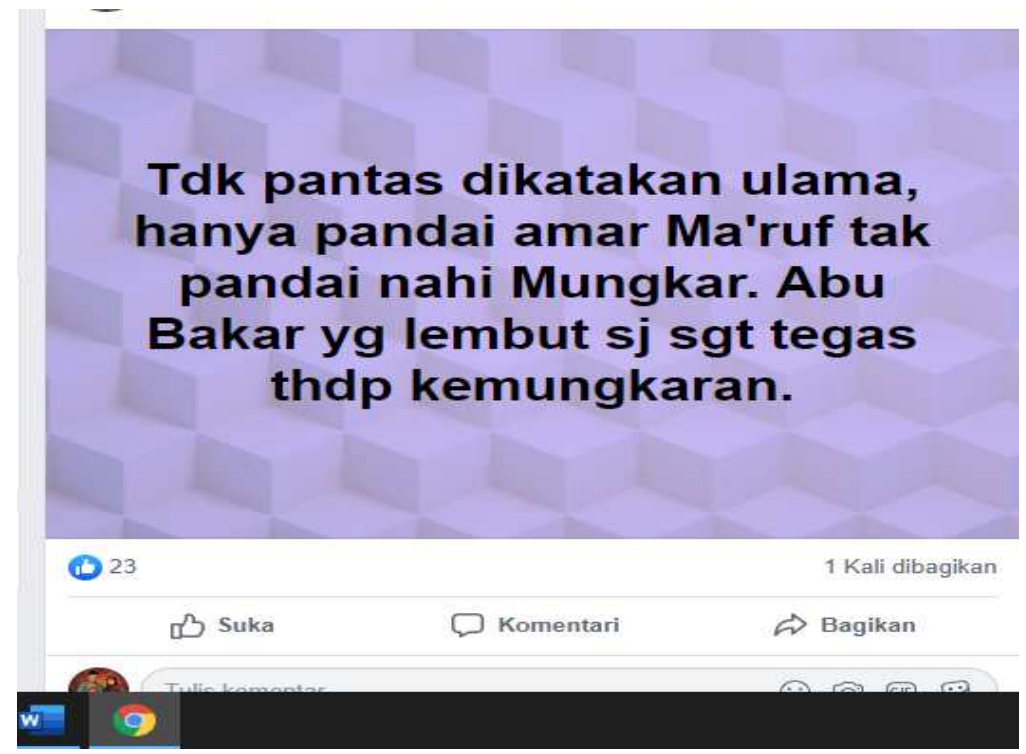

Fig. 2. Hoax and Hate Speech 2

\section{AlgorithmicEnclaves: The Rise of Tribal Nationalism}

In the 2019 presidential election, some observers argued that the algorithm determined the type of information presented to social media users based on the user's own interest. In this 
case, social media users tend to enter "filter bubbles" where they interact with similar information and insulate them from diverse and different views.

However, my observation shows that users in Indonesia usually have a large and diverse network of contacts (sometimes more than 1,000 "friends"), who open them to various forms of discussion. However, for social media users who are anti- or pro-Jokowi or anti- or pro-Probowo, conflicting information actually confirms their own point of view. Furthermore, this fact sharpens the hostile relations that they cultivate with the political opponents they support.

This dynamic perpetuates the formation of what I call an "algorithmic enclave". Algorithm pockets are formed when a group of individuals, driven by continuous interaction with the algorithm, seeks to form a shared online identity, to share with each other, defend their beliefs, and protect their resources from threats, both intrinsic and majestic.

The algorithm itself does not determine the formation of these bags. It is not information that functions to shape and sharpen differences between pockets, but rather how the information is shared, discussed, and clashed with regular opinions and beliefs between members in the bag.

In these algorithmic pockets, social media users often call the famous slogan "Second Jokowi", a mantra that pro Jokowi often uses while slogan 'make Indonesia great again' used by pro-Prabowo to suppress opponents' ideology. This slogan is used to claim and legitimize their own "tribal nationalism" or "tribal nationalism" while eliminating equality and justice for others.

\section{Conclusion}

There is no doubt that sectarianism and racism played significant roles in the election and social media, which were heavily utilized during the campaign, contributed to the increasing polarization among Indonesians. However, it is misleading to frame the contestation among ordinary citizens on social media in an oppositional binary, such as democratic versus undemocratic forces, pluralism versus sectarianism, or rational versus racist voters. Marked by the utilization of volunteers, buzzers, and micro-celebrities, the Indonesian presidential election in 2019 exemplifies the practice of post-truth politics in marketing the brand. While encouraging freedom of expression, social media also emboldens freedom to hate, where individuals exercise their right to voice their opinions while actively silencing others. Unraveling the complexity of the relationship between social media and electoral politics, I suggest that the mutual shaping between users and algorithms results in the formation of "algorithmic enclaves" that, in turn, produce multiple forms of tribal nationalism. Within these multiple online enclaves, social media users claim and legitimize their own versions of nationalism by excluding equality and justice for others.

Through the case of the 2019 presidential election, it can be observed the use of social media in political campaigns are commercial in nature and relies on marketing and imaging. Social media and market-driven campaigns deepen the gap between social groups and sharpen hostility and intolerance with one another.

\section{References}

[1] M. Michaelsen, New media vs. old politics the inter-net, social media, and democratisation in Pakistan. Berlin, Germany: fesmedia Asia Friedrich-Ebert-Stiftung, 2011.

[2] S. A. Arshad, Ali \& Hassan, "Role of new media in political discussion and changing 
voting behavior of university students," Int. Res. J. Soc. Sci., vol. 3, no. 7, pp. 4-9, 2014.

[3] M. Ahmad, Taufiq., Alvi, Aima., Ittefaq, "The use of Social media on Political Participation among university students: an analysis survey results from rural Pakistan," Sage Open, pp. 1-9, 2019, doi: DOI: 10.1177/2158244019864484.

[4] M. Lim, "Freedom to hate: social media, algorithmic enclaves, and the rise of tribal nationalism in Indonesia," Crit. Asian Stud., 2017, doi: DOI: 10.1080/14672715.2017.1341188.

[5] and S. L. B. Zhang, Weiwu, Thomas J. Johnson, Trent Seltzer, "The RevolutionWill Be Networked: The Influence of Social Networking Sites on Political Attitudes and Behavior,”Soc. Sci. Comput. Rev., vol. 28, no. 1, pp. 75-92, 2010.

[6] and K. F. K. Valenzuela, Sebastián, Namsu Park, "Is There Social Capital in a SocialNetwork Site? Facebook Use and College Students' Life Satisfaction, Trust, and Participation," J. Comput. Commun., vol. 14, no. 4, pp. 875-901, 2009.

[7] and J. M. G. Bertot, John C., Paul T. Jaeger, "Using ICTs to Create a Culture ofTransparency: E-government and Social Media as Openness and Anti-corruption Tools for Societies," Gov. Inf. Q., vol. 27, no. 3, pp. 264-271, 2010.

[8] D. Trottier, Social Media as Surveillance: Rethinking Visibility in a Converging World. London: Routledge, 2016.

[9] D. Boyd, "Facebook's Privacy Trainwreck: Exposure, Invasion, and Social Convergence," Convergence, vol. 14, no. 1, pp. 13-20, 2008.

[10] and M. G. Conroy, Meredith, Jessica T. Feezell, "Facebook and Political Engagement: A Study of Online Political Group Membership and Offline," Polit. Engagem. Comput. Hum. Behav., vol. 28, no. 5, pp. 1535-1546, 2012.

[11] and M. G. Allcott, Hunt, "Social Media and Fake News in the 2016 Election. NBER Working Paper," 2017. .

[12] K. Krippendorff, Content Analysis: An Introduction To Its Methodology. SAGE Publication, 2012.

[13] Z. „Azzah F. Khoiril Huda, “Pemilu Presiden 2019: Antara Kontestasi Politik dan Persaingan Pemicu Perpecahan Bangsa," in Seminar Nasional Hukum Universitas Negeri Semarang. Volume 4 Nomor 3 Tahun 2018, 2018, pp. 547-562.

[14] H. Surbakti, R., Supriyanto, D., \& Asy'ari, Merancang Sistem Politik Demokratis Merancang Sistem Politik Demokratis Menuju Pemerintahan Presidensial yang Efektif. Jakarta: Kemitraan bagi Pembaruan Tata Pemerintahan, 2011.

[15] Solihah, "Peluang dan tantangan pemilu serentak 2019 dalam perspektif politik," J. Ilm. Ilmu Pemerintahan., vol. 3, no. 1, pp. 73-88, 2018, doi: DOI: 10.14710/jiip.v3i1.3234.

\section{Authors Biography:}

1. Muh. Zuhri(ID SCOPUS; 57209253878):. Born in Klaten March 26, 1953. He is Syariah Professor in State Institute for Islamic Studies (IAIN) Salatiga Central Java Indonesia

2. Winarno (ID SCOPUS; 5720925994). Lecturer and Assoceate Professor in State Institute for Islamic Studies (IAIN) Salatiga. He has been head of the study program Tadris Matematika Tarbiyah faculty and teacher training (FTIK). He earned a Doctor in Researh and Education Evaluation State University Yogyakarta. His research interests and focus evaluation in education. He has published in a number of international journals scopus 
3. Prof. Dr. H. Budihardjo, M . Ag,: Born in Klaten, 2 Oktober 1954, Professor in State Institute for Islamic Studies (IAIN) Salatiga Central Java Indonesia

4. Guntur Cahyono, M. Pd.: Lecturer in State Institute for Islamic Studies (IAIN) Salatiga 